\title{
Komplike Yas: Derleme ve Vaka Çalışması
}

\author{
Ayşen Maraş \\ Orta Doğu Teknik Üniversitesi
}

\begin{abstract}
Özet
Yas süreci ve depresyon, Freud'un (1915/2000) Yas ve Melankoli üzerine makalesinden bu yana, birbiri ile ilişkili olarak değerlendirilmiş ve iki süreci ayrıștıran özellikler, kuramcılar ve klinisyenler tarafindan ilgi odağı olmuştur. Son dönemde, komplike yas kavramı, araştırmalar temelinde, kendine özgü bazı belirtileri kapsayacak şekilde tanımlanmıştır. Literatürdeki yaygın ismi ile komplike yas, süreğen kompleks yas bozukluğu olarak DSM-V tanı kitabına dahil edilmiştir. Bu tanının DSM-V'e dahil edilmesi, gelecekteki çalışmaları artırmak ve onlara yön vermek amacı taşımaktadır. Bu makalede, literatürdeki araştırmalara paralel olarak "komplike yas" kavramı kullanılmış; kaybın inkarı, ölen kişiye dair sürekli zihinsel meşguliyet, yoğun hasret ve kaybedilenle bir araya gelmek amacıyla intihar düşünceleri gibi belirtileri niteleyen bu kavramın, normal yas sürecinden farkına, komplike yasa yol açabilecek bazı faktörlere, komplike yasın bilişsel kavramsallaştırması ile bu temelde ilerleyen bir vaka çalışmasına yer verilmiştir.
\end{abstract}

Anahtar Kelimeler: Komplike yas, yas, psikoterapi, bilişsel model 


\title{
Komplike Yas: Derleme ve Vaka Çalışması
}

\author{
"Yas tutmaktan tamamen kaçınanlardan bazıları, sonunda çöker-çoğunlukla bir çeşit depresyonla.
} Bowlby, Attachment and Loss, 1982

Kayıp ve yas yaşantısı, literatürde, artmış depresyon oranı ile ilişkilendirilmektedir (Adler ve ark., 1994; Kessler, Kendler, Heath, Neale ve Eaves, 1992). Freud (1915/2000) Yas ve Melankoli üzerine yazdığı makalesinde, "Yasta dünya yoksullaşmış ve boşalmıştır, melankolide bu benin kendisidir" diyerek, yas ve depresyonun ilişkisine önemli bir açıklama getirmiştir. Yoksullaşmış "ben”, bireyin varoluşunda önemli bir yoksunluğuna işaret ediyor gibidir. Birey sadece bağl1lık duyduğu kişiyi değil, aynı zamanda kendi özdeğerini, özsaygısını, bütünlüğünü, rolünü veya yaşamdaki amacını da kaybetmiştir.

Doğal koşullarda, yas tutan bireyin, kaybın gerçekliğini kabul edebildiği, kaybedilen kişiye dair anılarından kolaylıkla bahsedebildiği, yaşamındaki zevk verici etkinlikleri ve ilişkilerini devam ettirebildiği bir sürece doğru ilerleme ve iyileşme yaşadığı kabul edilir (Maercker ve Lalor, 2012; Shear ve Shair, 2005). Bu iyileşme sürecinde, yas tutan birey, kaybettiği yakını ile ilişkisini iç dünyasında yeniden anlamdırır. Ancak bazı bireylerin yakınlarını kaybettikten sonra, geleceğe yönelik planlarının ve inançlarının yıkılması, kimlik ve rol kaybı ile yaşamlarını zorlayan yeni sorumluluklara uyum sağlamakta güçlük yaşamaları söz konusu olabilir (Mathew ve Marwit, 2004; Tomarken ve ark.,2008).

Son dönemlerde, klinisyenler DSM-V için “ komplike yas” (Complicated Grief) ad1 verilen, aynı zamanda "uzatılmış yas" veya "travmatik yas" da denilen, yeni bir tanı kategorisi üzerinde tartışmaktadırlar. Komplike yas, ölüme inanmama, öfke, yoğun özlem, kaybedilen kişiye ilişkin zihni meşgul eden düşünceler, suçluluk, kaçınma, çeşitli durumlara ve etkinliklere olan ilgi azalması ve kimlik/rol kaybı ile karakterize edilmektedir (Shear ve Shair, 2005). Bazı araştırmacılar, akut ve uzatılmış yas tepkileriyle karakterize edilen bu sendromun depresyon, endișe veya Travma Sonrası Stres Rahatsızlığı (TSSR) gibi var olan tanılarla kapsanabileceğini söylemektedirler (Zisook ve ark., 2012). Öte yandan, bazı araştırmacılar ise, her ne kadar depresyon ve TSSR ile bazı özellikleri paylaşıyor olsa da, komplike yasın kayba karşı verilen tepkilerden oluşan yeni bir tanı olduğunu ifade etmektedirler (Boelen ve Van den Bout, 2005; Craig, 2010; Harvard Mental Health Letter, 2011; Maccallum ve Bryant, 2011; Maercker ve Lalor, 2012; Ogrodniczuk ve ark., 2003). Büyük ölçüde örtüşen tanılama kriterleri, farklı araştırmacılar tarafından önerilmiş (Horowitz ve ark., 1997; Prigerson ve ark., 2009; Shear ve ark., 2011), bu çalışmalar sonucunda DSM-V'e "araştırma gerektiren alanlar" başlığı eklenmiş ve "Süreğen Kompleks Yas Bozukluğu" (Persistent Complex Bereavement Disorder) tanısı altında kriterler belirlenmiştir (bkz. Ek 1).

Yas, süreğen kompleks yas bozukluğu ve depresyon arasındaki farklar ve benzerliklerin daha çok araştırılması gerekliliğine karşın, komplike yas tepkileri depresyon ile sonuçlanabilmekte; böyle durumlarda, tedavinin yas süreci ile birlikte depresif belirtilere odaklanması önerilmektedir (Raphael ve Dobson, 2000;Worden, 2009).

Bu makalede, ilk olarak, yas sürecine ve yas sürecinin komplike yasa dönüşmesinde etken olabilen faktörlere yer verilecek; ilerleyen bölümlerinde ise komplike yas tepkilerinin depresyon 
semptomlarına dönüşmüş olduğu düşünülen bir vakanın, bilişsel model çerçevesinde formulasyonuna ve psikoterapi sürecine odaklanılacaktır.

\section{Yas Süreci ve Kuramsal Açıklamalara Genel Bakış}

İngilizcede yas için kullanılan grief sözcüğü Latince gravis sözcügünden gelmektedir ki bu sözcük de gravity sözcügünün köküdür ve "dayanmak; hayatta kalmak" anlamına gelmektedir (Hollis, 2004). Türkçede ise yas sözcüğü ilk olarak Uygurca metinlerde belirmekte ve "hüsran, zarar, ziyan" anlamına gelmektedir (www. nisanyansozluk.com). Psikoloji alanındaki çalışmalara konu olan yas tutma süreci, kaybın geri dönüşsüzlüğünün ve sonuçlarının sindirildiği veya hafızaya içselleştirildiği, hayata keyif ve memnuniyetle devam etme kapasitesinin yeniden kazanıldığı bir süreç olarak tanımlanabilir (Shear, 2012).

Yas, kayba verilen doğal bir karşılıktır, güçlü ve yoğun tepkiler içerir ve çoğunlukla uzun vadeli olumsuz sonuçlarla bağlantılı değildir (Love, 2007; Parkes, 2002). Her geçen gün büyüyen literatür, yasta ortaya çıkan geniş kapsamlı bilişlere, hislere, duygulara ve davranışlara işaret eder. Yasta, bilişsel açıdan, inkar, karmaşa, odaklanma bozukluğu, yönelimsizlik, unutkanlık, görsel ve işitsel sanrılar ve parçalanmış gerçek dünya bilgisi veya inançları görülebilir (Love, 2007; Worden, 1996, 2004).

Bilişsel tepkilerle ilişkili olarak, yasta çeşitli duygular, hisler ve davranışlar deneyimlenmektedir. Yakının kaybı, üzüntü, öfke, endişe, çaresizlik, yalnızlık ve suçluluk gibi duygulara sebep olmaktadır (Casarett, Kutner ve Abrahm, 2001; Love, 2007; Worden, 2004). Yas sürecinin fiziksel ve davranışsal bağlantıları ise şu şekilde sıralanabilir: kendine yabancılaşma, dalgınlık, sosyal içe çekilme, kaybedilene ilişkin rüyalar, kaybedileni hatırlatan yer, kişi ve nesnelerden kaçınma, ağlama, huzursuzluk, aşırı hareketlilik, enerji eksikliği, tat ve uyku bozuklukları ve diğer somatik şikayetler (Casarett, Kutner ve Abrahm, 2001; Worden, 2004).

Birçok kuramc1, kayıp ve yas sürecini anlamaya ve psikoterapi sürecine 1şık tutmaya çalışmıştır. Yas alanında öncü ve önemli bir çalışma gerçekleştiren Lindemann (1963), çalışmasında, yakınlarını kaybeden kişilerdeki yas tepkilerinin, somatik acı, kayıp kişiye dair düşüncelerle meşgul olma, suçluluk duygusu, öfke/düşmancıllık ve işlev kaybı içerdiğini ortaya koymuştur. Bununla birlikte, hayatta kalanların, kaybedilen yakının kişisel özelliklerini sergileme eğiliminde olduğunu gözlemlemiştir. Lindemann, aşırı aktivitede bulunma, sosyal çevre ile ilişkilerde bozulma, sosyal içe çekilme ve depresyon gibi ertelenmiş tepkilerin, ruhsal açıdan sağlıklı olmayan belirtiler olduğunu ifade etmiş; tedavi sürecinde, bu belirtilerin, doğal yas tepkilerine dönüşebilmesinin, iyileşme açısından önemli olduğunu söylemiştir.

Parkes'a göre (1998) ise yas süreci dört aşamadan oluşmaktadır: şok/hissizlik, özlem/arayış, karışıklık/çaresizlik, yeniden yapılanma/iyileşme. Bu yaklaşıma göre, kişi önce kaybın gerçekliğini kabullenemeyerek, bir çeşit hissizlik ve uyuşukluk yaşamakta, daha sonra kaybedilen kişi ile olan yaşantılara geri dönmeyi arzulamaktadır. Bu istek, bazen kaybedilen kişinin eşyalarını olduğu gibi koruma gibi davranışlarda kendini gösterebilmektedir. Karışıklık/çaresizlik aşamasında, bireyin kaybedilen kişinin dönmeyeceğini kavrayarak çaresizlik, çökkünlük ve işlevselliğin kaybı ile karakterize olan bir süreç yaşaması söz konusudur. Son aşamada ise, kişi yaşama devam edebilmek için hayatının parçalarını bir araya getirir ve yeniden yapılandırır.

Yas alanında bir diğer önemli kuramcı Kübler-Ross (1969) inkar, öfke, pazarlık, depresyon ve kabul aşamalarını içeren aşama kuramını geliştirmiştir. Kübler-Ross, inkar aşamasının, kişiye daha olgun savunma mekanizmaları kullanabilmesi için bir ön hazırlık dönemi sağladığını, daha sonra inkarın yerini öfke, hiddet ve gücenmişlik gibi hislere bıraktığını belirtmiştir. Kübler-Ross pazarlık aşamasını ise, reddedilen bir çocuğun, isteğini gerçekleştirebilmek için "iyi çocuk olma" 
sözü vermesine benzetmiştir. Bu pazarlıkların çoğu, Tanrı ile kayıp yaşayan kişi arasında gerçekleşmektedir. Depresyon ve kabul aşamalarında, kişi, üzüntü, suçluluk ve güçsüzlük hissederek kaybın gerçekliğini kavramakta ve önceki basamakları yaşadıysa "kaderini" kabullenebilmektedir. Kübler-Ross, son aşamanın bir "mutlu son” olmadığını, çeşitli duygular içerdiğini, bu aşamanın, bir hastası tarafından "uzun bir yolculuk öncesi son dinlenme" olarak tanımlandığını ifade etmiştir.

Son dönemlerde yas üzerine çalışan Worden (2009), klinik verilere dayanarak, önceki kuramcıların aşamalardan oluşan yaklaşımları yerine "görev yaklaşımı" olarak nitelediği bir yaklaşım önermiştir. Bu yaklaşıma göre, kişi, sırasıyla, kaybın gerçekliğini kabul etme, yas acısının üstesinden gelme, kaybedilenin olmadığı bir yaşama uyum sağlama, kaybedileni iç dünyada yeniden konumlandırarak hayata devam etme gibi görevleri gerçekleştirebilmelidir. Worden, önceki aşama kuramlarının (stages approach) önemini inkar etmediğini belirtmiş ancak yas tutma sürecinde, görev yaklaşımının, insanlara "güç ve aktif olma hissi” verdiğine dikkat çekmiştir.

Günümüzde, yas, ölen kişi olmadan yaşamaya uyum sağlanan doğal bir süreç olarak kabul edilmekle beraber, birçok öncül değişkenin etkisi ile bu tepkiler yoğun ve uzun süreli olabilmekte; kayıp yaşayan kişide komplike yas belirtileri görülebilmektedir.

\title{
Komplike Yas ve Yas Tutma Sürecini Etkileyen Faktörler
}

\author{
“...yası tutulmayan kayıplar yaşamımızı gölgeler, enerjimizi tüketir, bizim bă̆lanma yeteneğimizi zedeler. Ĕ̆ger yas \\ tutamıyorsak, eski meselelerin kölesi olarak kalırız ve şimdiki zamana ayak uyduramayız çünkü hala geçmişten gelen \\ bir ezgiyle dans etmekteyizdir." \\ Albert, aktaran Beder, 2004
}

Yukarıda da ifade edildiği gibi, komplike yas, ayrılma endişesi (örn., yoğun özlem, yalnızlık hissi, yeniden bir araya gelmek için ölme isteği, kaybedilen kişiye ilişkin düşüncelerle meşgul olma) ve diğer bilişsel, duygusal ve davranışsal semptomları (örn., karmaşa, inkar, kaçınma, öfke, hissizleşme, yaşamı devam ettirme güçlüğü) kapsamaktadır (Prigerson ve ark., 2009; Shear ve Shair, 2005; Shear ve ark., 2011).

Her ne kadar yas süreci büyük ölçüde bireysel gibi görünse de, klinisyenler ve araştırmacılar ilişkili faktörleri belirlemeye çalışmaktadırlar. Örneğin, kadın olmak ve düşük eğitim düzeyi komplike yas semptomları ile ilişkili bulunmuştur (Newson, Boelen ve Hek, 2011; Shear ve ark., 2011). Diğer ilişkili faktörler, takip eden paragraflarda kısaca özetlenecektir.

\section{Ölüm biçimi}

Ölümün, kazayla, intihar, cinayet ya da bir hastalık sebebiyle gerçekleşmesi, yas tepkilerini ve yas tutma sürecini etkileyecektir (Worden, 2009). Araştırmalar (Parkes ve Weiss, aktaran Worden, 2009), beklenmedik, şiddet içeren veya engellenebileceğine inanılan bir ölümün yas tutma sürecini uzatabileceğini ve komplike yas ve diğer psikolojik bozukluklar ile sonuçlanabileceğini belirtmektedir (Gamino, Sewell ve Easterling, 2000; Kristensen, Weisaeth ve Heir, 2012; Melhem ve ark., 2003; Newson ve ark., 2011).

\section{Kişisel İyilik Hali Geçmişi}

Geçmiş kayıplara bilişsel, duygusal ve davranışsal dengesizlikle tepki veren veya depresyon, kaygı bozukluğu veya diğer psikolojik bozukluk geçmişi olan insanlar, komplike yas tepkilerine daha yatkın olabilmektedir (Ghesquiere, Haidar ve Shear, 2011; HMHL, 2011). Bir çalışmada (Dell'Osso ve ark., 2011), komplike yas belirtileri gösteren kişilerin, Duygu Spektrumu 
Özbildirim Ölçeği (Mood Spectrum Self Report ) ile ölçülen manik ve depresif semptomları, sağlıklı kontrol grubununkilere göre anlamlı şekilde yüksek bulunmuştur. Yazarlar, siklotiminin komplike yas için bir yatkınlık faktörü olabileceğini öne sürmüşlerdir. Chiu ve arkadaşları (2010), komplike yas yaşayan kişilerin geçmişinde, komplike yas yaşamayanlara kıyasla, daha yüksek oranda duygu durum bozuklukları ve psikotik bozukluklar görüldüğü bulgusuna ulaşmışlardır. Bir derleme çalışmasında (Lobb ve ark., 2010), depresyon geçmişinin komplike yas belirtilerinin yoğunluğu ile ilişkili olduğu bulunmuştur. Ayrıca çeşitli çalışmalar (Lobb ve ark., 2010; Sung ve ark., 2011), komplike yas belirtileri sergileyen kişilerde, daha yüksek oranda alkol kullanımı, panik bozukluk ve obsesif kompulsif bozukluk olduğunu bulmuştur.

\section{Kaybedilen kişi ile ilişki ve Bağlanma Tarzı}

Kaybedilen kişinin hayatta kalanın yaşamında "kim olduğu” büyük önem taşır. Bu hem ilişkideki rolü (eş, çocuk, anne, arkadaş vb gibi) hem de kaybedilen kişiye ilişkin farklı umutlar ve beklentiler gibi ilişkinin farklı dinamiklerini kapsar (Worden, 2004). Kaybedilen kişiyle kişiler arası çatışma, bu kişiyle olan üst düzey etkileşim, kaybedilenle olan yakın akrabalık ilişkisi, güvensiz bağlanma, çocukluktaki ayrılma endişesi ve geçmişte ebeveynlerden birinin ölümü gibi zorluklar ile destekleyici bir kişiye olan yüksek düzey bağımlılık gibi faktörlerin komplike yas tepkilerini yordadığı bulunmuştur (Boelen ve ark., 2011; Bonanno ve ark., 2002; Gona ve K'Delant, 2011; Lobb ve ark., 2010; Melhem ve ark., 2003; Metzger ve Gray, 2008, Shear ve Shair, 2005).

\section{Kişilik Özellikleri}

Duygusal dengesizlik, aleksitimi, karamsarlık ve düşük özsaygı gibi bazı kişilik faktörleri, kaybı takiben oluşan olumsuz düşünce ve duygularla ilişkili bulunurken, iyimserlik gibi diğer kişilik değişkenleri yas tutma sürecinde koruyucudur (Boelen Van den Hout ve Bout, 2006; Boelen ve Van den Bout, 2010; Boelen ve ark., 2011; Lobb ve ark., 2010; Nakao, Kashiwagi ve Yano, 2005; Robinson ve Marwit, 2006; Tomarken ve ark., 2008; Worden, 1996; Worden, 2004). Buna ek olarak, Stroebe, Schut ve Stroebe'ye göre (2007), süreğen olumsuz duygulanımlar, yas tepkilerini yoğunlaştırabilirken, süreğen olumlu duygulanımlar ise yas sürecine bazen engel olabilmektedirler. Gona ve K'Delant (2011) ise olgunlaşmamış savunma tarzının yasın şiddetini belirlediğini ortaya koymuştur. Kişilik ve yas üzerine yapılan diğer bir çalışma (Tomarken ve ark., 2012), saplantılı, narsisistik ve histrionik kişilik tiplerinin umulduğu gibi komplike yas ile bağlantılı olmadığ 1 sonucuna varmıştır.

\section{Baş Etme Tarzı}

Bir derleme çalışmasında, aktif baş etme, olumlu yeniden yapılandırma, destek arama gibi baş etme yöntemlerinin daha az komplike yas belirtisi ile ilişkili olduğu belirtilmiştir (Lobb ve ark., 2010). Bunlara ek olarak, problem çözme davranışındaki eksikliklerin komplike yas yaşayan bireylerde belirgin olduğu görülmüştür (Maccaulm ve Bryant, 2010). Pek çok çalışmada (Boelen ve Klugkist, 2011; Boelen ve Van den Bout, 2010; Boelen, Van den Hout ve Van den Bout, 2006; Stroebe, Boelen, Van den Hout, Stroebe, Salemlnk ve Van den Bout, 2007), bilişsel kaçınma (örn. düşünce baskılama, ruminasyon) ve kaygılı ve depresif kaçınma olarak ayrıştırılan davranışsal kaçınma, komplike yas belirtilerinin şiddeti ile ilişkili bulunmuştur. Neimeyer (2006), araştırma bulgularına dayanarak, kaygılı (örn. kaybedilene ilişkin düşünce, duygu ve anılardan kaçınma) ve depresif kaçınma (örn. eğlenceli gündelik aktivitelerden kaçınma) stratejilerinin kayıptan sonra 
uyumu zorlaştırdığını ifade etmiştir. Bir başka çalışma, kayıptan sonra geçen süre ve yaşam boyu travma sayısı kontrol edildiğinde, kaçınmacı duygusal baş etmenin komplike yasın bir göstergesi olduğunu bulmuştur (Schnider ve Elhai, 2007). Dindarlık ise daha düşük düzeyde komplike yas tepkileri ile ilişkili bulunmuştur (Cowhock, Ellestad, Meador, Koenig, Hoosen ve Swamy, 2011; Kelley ve Chan, 2012). Bir diğer çalışmada (Burton ve ark., 2012), komplike yas belirtileri gösteren bireylerin, yakınını kaybetmiş olan ama bu belirtileri sergilemeyen bireylere göre baş etme yöntemlerinin esnek olmadığı, farklı yöntemler yerine belli kısıtlı yöntemleri kullandıkları görülmüştür.

\section{Bilişsel Şema ve İnanç Sistemleri}

Yas tutan bireylerin olumsuz inançları (örn. "Ben değersizim”, "Hayat anlamsız") ve yorumlamaları (örn., "Ben acıya tahammül edemem") doğrudan komplike yas semptomlarıyla sonuçlanabilir, kaçınma ve ruminasyon gibi işlevsel olmayan başa çıkma stratejilerine yol açabilir ve kayıp yaşantısının otobiyografik hafızaya entegrasyonunu engelleyebilir (Boelen ve ark., 2006; Neimeyer, 2006). Her ne kadar bilişsel şemaların ve inanç sistemlerinin komplike yasta önemli olduğu belirtilmiş olsa da, bu ilişkiyi inceleyen çalışma sayısı çok azdır. Maercker, Bonnanno, Znoj ve Horowitz (1998), kayıptan altı ay sonra alınan yaşantı öykülerinde sıklıkla beliren olumlu temaların (örn., güven, hayranlık, yakınlık), kaybın on dördüncü ayında daha az komplike yas semptomu ile ilişkili olduğunu belirtmiştir. Currier, Holland ve Neimeyer (2009) hayatın anlamsızlığına inanan, düşük özdeğere sahip kişilerin, yakınlarını kaybetmelerinin ardından daha fazla 1zdırap (distress) belirtisi gösterdiğini bulmuştur.

\section{Sosyal Destek ve Güncel Stresli Yaşam Olayları}

Lobb ve arkadaşları (2010) tarafından yapılan bir derlemede, sosyal desteğin ulaşılabilirliği ile kişinin bu destekten tatmin düzeyindeki artışın, azalmış komplike yas tepkileri ile ilişkili olduğu belirtilmiştir. Buna ek olarak, kayıp dönemindeki yoğun 1zdırabın (distress), birey için yas tutma sürecini zorlaştırması sebebiyle komplike yas tepkileriyle ilişkili olduğu bulunmuştur (Ghesquiere, Haidar ve Shear, 2011; Lobb ve ark., 2010).

\section{Komplike Yasın Kavramsallaştırılması ve Tedavisi}

Ölüm biçimi, kişisel iyilik hali ve kaybedilen kişi ile ilişki gibi yukarıda anlatılan birçok değişkenden etkilenen komplike yas tepkilerine, ya da DSM-V'deki tanımıyla Süreğen Kompleks Yas Bozukluğuna, yönelik belirli psikoterapi yaklaşımları, önemli bir çalışma alanı oluşturmaktadır. Boelen ve arkadaşları (2006), psikoterapi sürecini yönlendirebilecek bilişsel-davranışçı bir model önermişlerdir. Bu modele göre, ayrılık ızdırabı (örn., hasret, kayıp ile zihinsel meşguliyet) ve travmatik ızdırap (örn., inkar, hissizleşme) komplike yasın temel belirtileridir. Bireysel yatkınlık faktörleri, kayıp olayının özellikleri ve kaybın gerçekleştiği koşulları içeren arka plan değişkenleri, temel süreçler yolu ile, komplike yas belirtilerine yol açar. Temel süreçler, ayrılığın otobiyografik hafizada entegrasyon zorluklarını, olumsuz inanç ve yorumları, kaygılı ve depresif kaçınma stratejilerini içermektedir. Şekil 1.'de komplike yasın, bilişsel davranışçı kavramsallaştırılması sunulmuştur. 

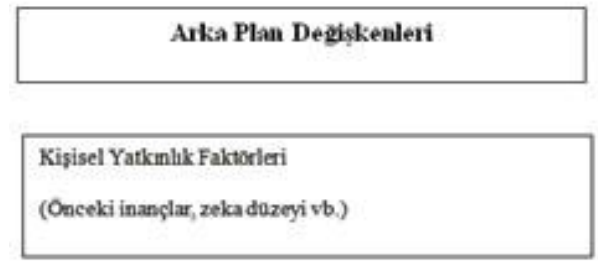

Kayp yasantsmm ozellikderi

(Kaybedilen kişi ile ilişkinin ozelliklen, otum biçimivb.)

Kaysp Kogullan

(Sosyal çevrenin kayba iliskin tepkileri, ikincil kayplar)
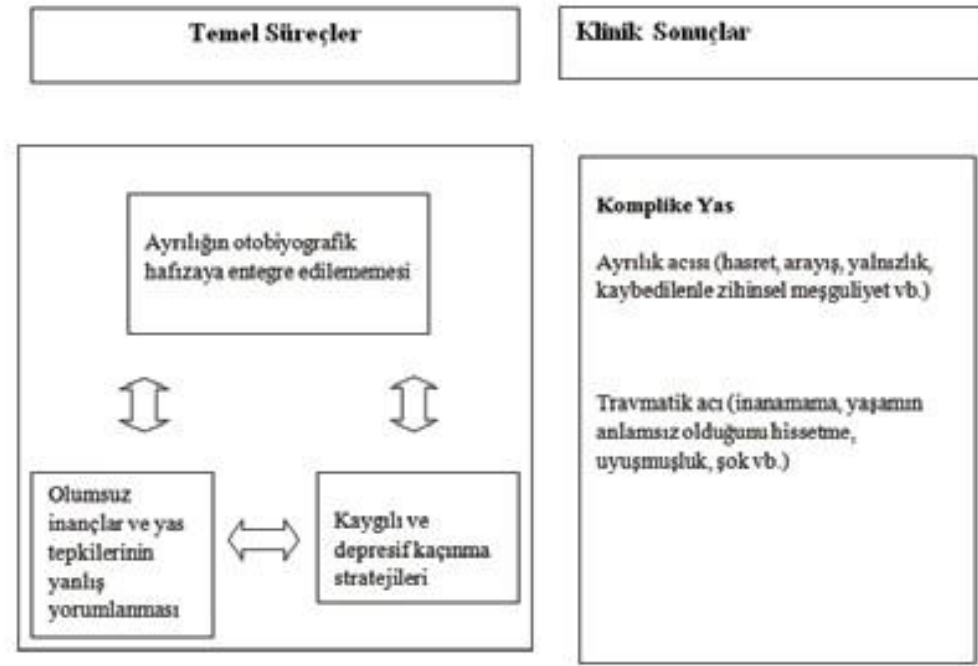

Şekil 1. Komplike Yasın Bilişsel Kavramsallaştırılması

Bu modele göre (Boelen ve ark., 2006), temel süreçler, arka plan değişkenlerinin varlığından etkilenerek ve birbiri ile etkileşimde bulunarak, komplike yas belirtilerine yol açabilirler.

\section{Temel Süreçlerin Komplike Yas Belirtileri Üzerindeki Etkisi}

Bilişler (olumsuz inançlar ve yas tepkilerinin yanlış yorumlanması) komplike yas belirtilerini üç farklı şekilde etkileyebilir: 1) doğrudan komplike yas semptomlarına yol açar, 2) kayıp yaşantısının var olan otobiyografik bilgilere uyumunu engeller, 3) kaçınma stratejilerini arttırır. Kayıp yaşantısı ile kişinin önceden sahip olduğu ancak aktif durumda olmayan olumsuz inançları tetiklenebildiği gibi, önceki inanç ve gelecek beklentileri de yıkıntıya uğrayabilir. Tetiklenen ya da yeni oluşan olumsuz inançlar, travmatik ya da ayrılığa ilişkin ızdıraba yol açabilir. Kayıp yaşantısının, kişinin otobiyografik hafızasındaki uyumu gerçekleşemediğinde ise, bu yaşantı, kişinin zihninde ayrık, belirgin ve yüksek oranda duygu yüklü kalmaya devam eder (Boelen ve ark., 2006). Kişi davetsiz ve otomatik şekilde ortaya çıkan hislere ve anılara açık hale gelir. Hafızadaki entegrasyonun eksikliği, aynı zamanda, kişinin "kaybın gerçekliğini kabullenememesi” ile yakından ilişkilidir. Olumsuz inançlar, bu entegrasyonun sağlanmasında engelleyici rol oynayabilir.

Bir diğer temel süreç olan kaçınma stratejileri ikiye ayrılmaktadır: depresif ve kaygılı. Kaygılı kaçınma stratejileri, kişi, kaybın ve ilişkili düşüncelerin, hislerin ve anıların gerçekliğiyle yüzleşmenin deliliğe, kontrol kaybına veya dayanılmaz sonuçlara sebep olacağına inandığı zaman kullanılır (Boelen ve ark., 2006; Boelen ve Van den Bout, 2010). Yas tutan kişi kaybedilen kişiyi hatırlatan durumlardan, insanlardan ve eşyalardan kaçınabilir. Sıkıntı verici anıları bastırabilir veya kaybın gerçekliğini kabul etmemek için bir kaçış yolu düşünmekle meşgul olabilir. Öte yandan, yas tutan birey, kaybedilen kişiden hala yaşıyormuş gibi bahsederek, onunla ilgili eşyalara özen göstererek veya bu kişiyle içsel bir diyalog kurarak, bu kişiyle güçlü bir bağ kurmayı sürdürebilir. Kaygılı kaçınma, her zaman zarar verici olmamakla birlikte, çoğunlukla hissizleşme, duygularda körelme veya sosyal içe çekilme gibi travmatik sıkıntı semptomlarına yol açar. Depresif kaçınma stratejileri ise, hareketsizlik, sosyal veya mesleki etkinliklerden uzaklaşma gibi kişinin kendini geri çekerek zevk verici aktivitelerden uzaklaşmasını içerir. Kişi bu geri çekilme ile olumlu anılar yaşama şansını da engellemiş olur (Boelen ve ark., 2006; Boelen ve Van den Bout, 
2010). Kişi bu stratejiler ile kayıp sonucu oluşan yeni yaşam koşullarından kaçınmaya çabalar. Gerekli becerilerin eksikliği ise her iki kaçınma türüne yol açan önemli faktörlerden olabilir. Özetle, kaygılı ve depresif kaçınma stratejileri, olumsuz inançlardan ve hafizadaki entegrasyon eksikliğinden beslenerek, beslendiği bu inançların güçlenmesine yol açar, entegrasyonu engeller ve komplike yas tepkileri ile sonuçlanabilir.

\section{Arka Plan Değişkenlerinin Temel Süreçlere Etkisi}

Yetişkin bağlanma tarzı veya entellektüel beceri gibi bireysel yatkınlık faktörleri, ayrılık yaşantısının hafızayla bütünleştirilmesini etkileyebilir (Boelen ve ark., 2006). Örneğin, önceki paragraflarda bahsedildiği gibi, güvensiz bağlanma tarzına sahip yetişkinler kayba ve ayrılmaya uyum sağlamayı zor bulabilir. Kayıp olayının özellikleri de (örn., kaza, intihar, cinayet olması), şiddet içeren ölümlerin istemsiz rahatsız edici anıların zihni işgal etmesine sebep olduğu durumlardaki gibi, hafızadaki bütünleşmeyi etkileyebilir. Kayıp koşullarının özellikleri, kayıp yaşantısının, otobiyografik hafızada bütünleştirilmesini etkileyen bir diğer arka plan değişkenidir. Sosyal çevre, yas tutan kişiyi olağan yaşamına devam etmeye teşvik ettiğinde yas sürecini destekleyebilir. Öte yandan, eğer sosyal çevre kaybı kabullenmezse, bu durum, kişinin yas sürecini zorlaştırabilir.

Arka plan değişkenlerinin inançlar üzerindeki etkileriyle ilişkili olarak, kişilik, özellikle duygusal dengesizlik (neuroticism) gibi arka plan değişkenleri bireyin benliğini ve dünyayı olumsuz bir şekilde görmesine yol açabilir (Clark, aktaran Boelen ve ark., 2006). Kayıp olayının özellikleri (örn. travmatik ölüm, ölen kişiyle olan ilişkinin doğası) kişinin var olan olumsuz inançlarını ve düşünme tarzını güçlendirebilir. Örneğin, yüksek ölçüde destekleyici bir yakının kaybı, kaybı yaşayan kişinin benlik algısını bozabilir. Kayıp koşullarının özellikleri (örn. gelir gibi ikincil kayıplar) olumsuz inançları etkileyebilir. Aynı zamanda, sosyal çevrenin kayba nasıl tepki verdiği de (anlayışsız veya ilgisiz tepkiler gibi), olumsuz düşünme tarzını güçlendirebilir.

Arka plan değişkenlerinin kaçınma stratejileri üzerindeki etkileri düşünüldüğünde, özgüven eksikliği gibi bireysel yatkınlık faktörlerinin yas tutan insanın depresif bir şekilde geri çekilmesiyle sonuçlandığı söylenebilir (Boelen ve ark., 2006; Boelen ve ark., 2010). Kayıp yaşantısının ve koşullarının özellikleri de kaçınma stratejilerini etkileyebilir. Örneğin, kaybedilen kişiyle bağımlı bir ilişkisi olan birey, kaybın gerçekliğini kabullenmekte daha büyük bir zorluk yaşayabilir. Bunlara ek olarak, destekleyici arkadaşların varlığı kişinin hareketsizliğinin azalmasına yol açabilirken, arkadaşların eksikliği gibi koşullar geri çekilmeyi güçlendirir.

\section{Psikoterapide Değerlendirme Süreci}

“Ölürsem annemle kavuşabilir miyim?”

N., seanslardan.

N., psikoterapi için başvurduğunda otuz bir yaşındaydı. Bir buçuk yıl önce kanser olan annesini kaybetmişti. N., kendisine önerilen antidepresan ilaçları aldığında uyuşukluk hissettiğini ve çok uyuduğunu düşündüğü için, ilaç tedavisini reddetmiş ve psikiyatrist tarafından psikoterapi amaçlı yönlendirilmişti. N., babası, üvey annesi ve on sekiz yaşındaki erkek kardeşi ile yaşıyordu. N. ve ailesi, annesinin ölümünden kısa bir süre sonra, babasının işi nedeniyle yaşadıkları şehirden başka bir şehre taşınmışlardı.

Değerlendirme görüşmelerinde, günlük işlerine ve mesleğine devam etme isteksizliği, aşırı uyuma, düşük enerji, yorgunluk hissi, konsantrasyon eksikliği, unutkanlık ve geleceğe yönelik umutsuzluk hisleri belirgindi. N., birçok defa intihar etmeyi düşündüğünü belirtti ve amacinın “annesi ile kavuşmak” olduğunu söyledi. N.'nin kayıp yaşantısından bahsetmekte yaşadığı güçlük dikkat çekiciydi. Annesi için “öldü” diyemiyor ve kayıp yașantısına ilișkin anılarını bütünsel 
olarak hatırlamakta güçlük çekiyordu. Rüyalarında annesini gördügü günlerin ertesinde, annesi gerçekten hayattaymış hissine kapılarak mutluluk duyduğunu ifade ediyordu. N., kayıp yaşantısının ardından birkaç gün ağladıktan sonra, bunun bir işe yaramayacağına karar vererek sustuğunu belirtti. Annesinin ölümünden sonra kendini "uyuşmuş, unutkan, aklı havada" olarak tanımlıyordu. Ancak son dönemlerde, etrafındakilere karşı çok kolay öfkelendiğini fark ediyordu. N., zaman geçtikçe iyileşmek yerine daha da kötüleştiğini hissettiğini, bu nedenle yardım almaya karar verdiğini söyledi. Yaşamın anlamsız ve boş olduğunu ifade eden N.'nin herhangi bir gelecek planı yoktu ve "ölmüş olmayı" diliyordu.

Değerlendirme görüşmelerinde N.’ye Beck Depresyon Envanteri (BDE) ve Minnesota Çok Yönlü Kişilik (MMPI) Envanteri uyguland1. N., bu uygulamalarda oldukça işbirlikçi idi. Değerlendirme görüşmeleri, BDE'den aldığı 23 puan ve MMPI sonuçları, depresif belirtilerinin varlığına işaret ediyordu. MMPI profilinde, depresyon, psikasteni ve sosyal izolasyon alt testlerinde yükselme olması, sosyal kaygı, sosyal beceri ve depresif belirtilerin psikoterapi sürecinde çalışılmasının önemli olacağına işaret ediyordu. Bu depresif belirtiler annesinin ölümü ile başlamıştı. $\mathrm{Bu}$ belirtilerin temelinde olduğu düşünülen komplike yas, psikoterapi sürecinin odak noktasını oluşturdu.

N., kendini içe dönük biri olarak tanımlıyordu. Çok az kişi ile duygusal paylaşımda bulunabildiğini söyleyen N.'nin duygularını adlandırmakta ve anlamlandırmakta yaşadığı güçlük belirgindi. N.'nin yakın bir arkadaşı vardı ancak onun kendisinden farklı, yaşamını bütün ve destekleyici bir aile ile geçiren şanslı biri olduğunu, kendisini tam olarak anlayamayacağını düşünüyordu. N.’nin kaybettiği öz annesi ve babası, N. sekiz yaşındayken ayrılmışlardı. N., bu ayrılma gerçekleşmeden önceki süreci de çatışmalı, annesinin babasına kızarak zaman zaman evi terk ettiği, anneannesinde kaldığı bir süreç olarak anlatıyordu. Anne ve babasının, ayrılma kararı da annesinin, evi terkederek anneannesinde kaldığı bir dönemde verilmişti. Babası, olağan davranış1 olan annesini dönmesi için ikna etmeyi reddetmiş ve boşanmaya karar verdiğini söylemişti. N., annesinin bu beklenmedik karar karşısında şaşkın ve sessiz kaldığını, kısa sürede boşanmanın gerçekleştiğini belirtti. Babası, boşandıktan sonraki yıl içinde yeni bir evlilik yapmıştı. N.'nin babasının maddi olanakları daha iyi olduğu için, N. babasının yanında kalmıştı. Ancak yetişme sürecindeki aile içi çatışmalar nedeniyle bakım veren kişisi oldukça sık değişmek zorunda kalmıştı. N., 13 yaşına kadar üvey annesi ve babası ile yaşamış, 13 yaşındayken erkek kardeşi dünyaya gelmişti. N., üvey annesi ile olan ilişkisinin, erkek kardeşi olana kadar "daha yakınken", kardeşi dünyaya geldikten sonra uzaklaştığını, üvey annesinin "her zaman erkek kardeşini ön planda tuttuğunu” söyledi. Bu süreçte, üvey annesi, N.' yi “dışarıda arkadaşları ile çok uzun vakit geçirmek”, “ders çalışmamak”, “evde sorumluluk almamak” gibi konularda suçlamıştı.

N.'nin öz annesi geçmişte beş yıl kadar yurt dışında yaşamış ve işçi olarak çalışmıştı. N., on beş yaşına kadar onu tatil dönemlerinde ziyaret edebilmişti. Öz annesi ile geçirdiği zamanlarda kendisini ona oldukça yakın hissettiğini, annesinin her şeyi ile ilgilendiğini, saatlerce baş başa sohbet ettiklerini, birbirlerine özel yaşamlarından bahsettiklerini ve birlikte uyuduklarını belirtmişti. N. annesini "harika" birisi olarak tanımlıyordu.

N., annesinin vefatından kısa süre sonra, babasının işi nedeniyle yeni bir şehre geldiklerini söyledi. Bu yeni şehirde kimseyi tanımadığı için kayıp yaşantısını ise kimse ile paylaşmamayı tercih ediyordu. Yaşamına “sanki hiçbir şey olmamış gibi” devam etmeye çalışmıştı. Üvey annesi ile ise oldukça mesafeli olarak tanımladığı bir ilişkisi vardı. N., öz annesi ile boşandıktan sonra görüşmemeyi tercih eden babasının, N.’nin “ne yaşadığını anlamadığını” söylüyordu ve bu durum N.'yi daha da suskunluğa itiyor gibi görünüyordu. 


\section{Psikoterapi Süreci}

-Geriye mi dönmeliyim?

-İleri doğru gittiğinde, nereye kaçarsan kaç, seni tehlike ve kötülük bekleyecek; çünkü seni yönlendiren o (gölge), senin ne yöne doğru gitmen gerektiğini o seçiyor. Bu yolu sen seçmelisin. Seni izleyeni izlemelisin. Avcryı avlamalisin.

Le Guin, Yerdeniz Büyücüsü, 1999, s.128

Vaka formulasyonunda, N.'nin komplike yas belirtilerinin, depresif belirtilere yol açtı̆̆ düşünülerek Boelen'in Bilişsel Modeli (2006) temel alındı. Boelen ve arkadaşları (2006) komplike yas tedavisinin üç amacı olması gerektiğini vurgulamaktadır: 1) kayıp zihinsel olarak işlemlenmeli ve otobiyografik hafizada entegre edilmelidir 2) işlevsel olmayan inanç ve yorumlar belirlenerek, işlevsel olanlar ile yer değiştirmelidir 3) Kaygılı ve depresif kaçınma stratejilerinin yerini uyuma yönelik yeni stratejiler almalıdır. Kuramcılar, bilişsel davranışçı tekniklerin kullanımında herhangi bir kısıtlama olmaması gerektiğini söylemekte psikoterapi hedefleri doğrultusunda psikoeğitim, Sokratik sorgulama ve bilişsel yeniden yapılandırma gibi yöntemlerin kullanılmasını önermektedirler.

Psikoterapi sürecinin ilk aşamasında, N. ile intihar mutabakatı yapıldı ve öncelikli olarak N.'nin kabul edildiğini hissettiği bir terapötik işbirliğinin kurulmasına odaklanıldı. N.'nin hasret, kaybı inkar, geleceği öngörememe gibi yaşantılarının kayıp sürecinde karşılaşılan deneyimler olduğu bilgisinin paylaşılması ve kayıp sürecine ilişkin psikoeğitim, N.'nin bu tepkilerinin doğallığını kabullenmesine destek oldu. N., güvenli psikoterapi ilişkisi ve kayıp sürecine ilişkin bilgilendirme sonrasında duygularına daha açık olmaya başladı. İlerleyen süreçte, N.'nin kayıp yaşantısını kabülü, bu yaşantıyı iç dünyasına entegre edebilmesi ve kayıp sonrasındaki dış koşullara uyum sağlayabilmesi hedeflendi. Bu amaçla, seanslarda N.'nin kayıp yaşantısı, bu yaşantıya ve annesi ile ilişkisine yüklediği anlam ve kaybın somut ve soyut sonuçları ele alındı.

N.'nin duygusal ve fiziksel yakınlık hissedebildiği, olumlu duygularını ve özdeğerini besleyen en önemli ilişkisinin annesi ile olan ilişkisi olması, N.'nin yas sürecini zorlaştırmıştı. N., duygularını ve yaşantılarını yalnızca annesi ile paylaşabildiğini, kabul, onay ve değer gördügünü hissediyordu. Öz annesi, üvey annesinin aksine suçlayıcı davranmıyor ve sıklıkla "birlikte yaşayamadıkları yılları telafi etme ve hep birlikte olma isteğinden" söz ediyordu. N., annesinin ölümünü kabullenmekte güçlük çekmekte, kayıp yaşantısına ilişkin düşüncelerden kaçınmaktaydı. Ancak ölümüne dair rahatsız edici rüyalar görmekte ve hayatta olduğuna ilişkin kurduğu gündüz düşleri, gününün büyük bir bölümünü kaplamaktaydı. Bu durum, N.'nin kayıp yaşantısını varolan anıları ile entegre etmekte güçlük yaşadığını, entegrasyonun eksikliğinin ise gün içinde zihnini meşgul eden, kayba ilişkin çeşitli düşlere yol açtığını düşündürüyordu. N.’nin gündüz düşlerinden biri şöyleydi: "Uçaktayım... Uçak düşüyor... Herkes iyi... Kurtuluyor... Yaralı bir kadın görüyorum. Ölü belki de... Ben de yaralıyım, ölmek üzereyim... Hastaneye kaldırılıyorum."

N.'nin kayıp yaşantısına ilişkin anılar ve yaşantılara odaklanıldığında, N.'nin uyuşmuşluk hissi yerini öfke, suçluluk ve kıskançlık gibi duygulara bırakabildi. Hayatta olduğu süreçte, annesinin, eşi ile yakınlığını kıskanıyor ve eşinin annesine uygun biri olmadığını düşünüyordu. Annesinin ölümünden sonra, annesinin eşine duyduğu öfke artmıştı. Onu annesini mutlu edememek ile suçlamıştı. Çocukluk sürecinde "yeterince" bir arada olamadığını hissettiği annesine karşı ikircikli duyguları bulunuyordu. Bu ikirciklilik, hastalık sürecinde yaşadığı duyguları da "başa çıkamayacağı kadar" ağırlaştırmış, N. de bu duygulardan kaçınmaya çalışmıştı. Bu kaçınma ise kendisine yönelik öfke ile suçluluk duygularının belirginleşmesine yol açmıştı. Hastalık sürecinde annesine duyduğu öfke ve yakınlık ihtiyacı, içsel çatışma yaşamasına yol açmış, annesinin vefatından sonra "sanki annesine destek olamaması, hastalık sürecinde her isteğini yerine getirememiş olması onun ölümüne yol açmış hissine” kapılmıştı. N.’nin gerçekçi olmayan suçluluk duygusu, psikoterapi 
sürecinde duygusal olarak ifade ve tekrar yapılandırılma firsatı bulduğunda, N. kendine yönelttiği öfkenin annesine yönelik kısmına dair farkındalık yaşadı ve kendisine bu duyguları yaşama alanı ve firsatı verdi.

N.'nin "ben kötü biriyim/ değersizim/çaresizim”" gibi, yaşantılarında kendinin ve insanların yerini, duygu, düşünce ve davranışlarını olduğundan farklı değerlendirmesine yol açan inançları bulunuyordu. Bu inançlar komplike yas belirtilerini ve depresif belirtileri arttırıyordu. Bunlara ek olarak, N. kayıp yaşantısını ve yasını aile bireyleri ile paylaşamıyordu. Uzun yıllar önce ayrılmış olan anne ve babası birbirlerine karşı yoğun öfke duymuş ve mecbur hissetmedikçe görüşmemişlerdi. Annesinin ölümünün ardından ise babası bu kayıp ile ilgili konuşmamayı tercih etmiş, söz açıldığında ise ölen eski eşine dair öfkesi ve onun ne kadar örnek alınmaktan kaçınılması gereken bir kişi olduğuna dair yorum ve öğütleri ön plana çıkmıştı. N.'nin üvey annesi ile ilişkisi de mesafeli ve olumsuz duygular ile yüklüydü. N., üvey annesinin N.'yi suçlamak için hiçbir firsatı kaçırmadığını ifade ediyordu. Bir keresinde "Senin gibi bir kızı olunca insan üzüntüden ölebilir" ifadesini kullandığını belirtti. N., psikoterapi sürecinde, üvey annesinin, kendi oğluna karşı ilgili ve destekleyici tavrının, değersizlik hislerini arttırdığını fark etti. N., kaçınarak baş etmeye çalıştığı anılarının, kayıp yaşantısı ve güncel ilişkilerinin ele alınması ile bunlara ilişkin farkındalığının verdiği duygusal rahatlama ile güncel yaşamında kendisini zorlayan durumlarla başa çıkmaya ilişkin adımlar atmaya başladı. İş yaşamında, fikirlerini belirtmeyip "susarak" diye tanımladığı başa çıkma tarzını azaltmaya, etrafındakilere duygu ve düşüncelerini ifade edebilmeye başladı. Yaşam öyküsünü, hafızasında entegre etmek adına olumlu adımlar atan N., bu öyküde "fikirlerine değer verilmeyen, hiçbir şey sorulmayan" biri olarak yoğun çaresizlik duyduğunu ifade etti.

N.'nin eğer yas tutmaya, üzüntüsünü yaşamaya izin verirse “kontrolünü kaybedeceği”ne yönelik varsayımları vardı. Duygularını ifade etmekte yaşadığı güçlük "Güçlü olmalısın. Duygularını göstermemelisin” inancı ile besleniyordu. Bu inanç ve varsayımlar, N.'nin kaygılı başa çıkma stratejileri kullanmasına yol açıyor, N. düşünce ve duygularından kaçınmaya çalışıyordu. N.'nin kullandığ 1 depresif ve kaygılı başa çıkma yöntemleri, psikoterapinin başlangıç aşamasında, seanslara geç gelmesinde, seansları iptal etmesinde ve bir önceki seansta konuşulanları unutmasında ortaya çıkıyordu. N.'nin düşünce, inanç ve varsayımları üzerinde çalışıldığında; N., geçmiş yaşam öyküsünde, duygusal desteğe ihtiyaç duyduğu zamanlarda, ebeveynlerinin kendi çatışmaları nedeniyle, N.'nin ihtiyaçlarına ve destek ihtiyacına karşılık verememiş olmasına karşın hissettiği çaresizlik ele alındığında, N. şimdiki yaşamında, destek aradığı zaman, kendi ihtiyaç ve duygularını ifade ettiğinde, ilişkilerinde etkin bir rol alabildiğini; yakınlarından sosyal ve duygusal destek alabildiğini fark etti. N.'nin yaşamındaki insanlarla paylaşımda bulunabilmesini destekleyen seans içi canlandırmalar (role-play), N.'nin kendini ifade edebilme provası yapabilmesine olanak sağladi.

Depresif kaçınma stratejileri kullanan N., iş ve sosyal yaşamında da geri çekilme eğilimindeydi. Sabahları yataktan kalkmakta güçlük yaşıyor, uzun süre kimse ile iletişim kurmak istemediği içe çekilmiş zamanlar geçiriyordu. Bu depresif kaçınma stratejilerinin uyum sağlayıcı başa çıkma stratejileri ile yer değiştirmesine ilişkin çalışılması ve bu süreçte sosyal becerilere ilişkin yapılan bilgilendirme ile seans içi canlandırmalar, N'nin sosyal yaşam içine daha çok katılabilmesine destek oldu. Seans içi yapılan canlandırmalardan sonra, babası ile annesinin ölümüne ilişskin hislerini ve babasının desteğine ihtiyaç duyduğunu, babası ile paylaşma cesaretini gösterdi. Bu paylaşım N. için oldukça duygu yüklü ve önemliydi. N., bu paylaşımı, kaybının ve yasının kabülü olarak değerlendiriyordu. Psikoterapi sürecinde, N.'nin davranışsal aktivitelerini arttırmaya yönelik kurulan işbirliği, yaşamına spor ve İtalyanca kursu gibi yeni aktiviteler eklemesine olanak sağladı. Yirmi beş seanstan oluşan psikoterapi sürecinde, psikoterapist ile işbirliği kuran ve yasını yaşamaya dair kendisine izin veren N., cesaretli ve olumlu adımlar atabildi. 
Psikoterapi süreci genel olarak değerlendirildiğinde, N. ile kurulan terapötik işbirliği ve Boelen'in (2006) bilişsel modeli temelli yaklaşımının N.'nin yas sürecini ele almakta faydalı olduğu düşünülmektedir. Olumlu ve çalışmaya olanak sağlayan bir psikoterapi ilişkisi, diğer yaklaşımlarda olduğu gibi bilişsel yaklaşım için de oldukça önemlidir. Wright ve Davis (1994), psikoterapi ilişkisini konu alan makalalerinde, psikoterapi ilişkisinin iyileşme açısından önemine dikkat çekmiş ve bu ilişkiyi kurabilmenin standart kuralları olmadığını ifade etmişlerdir.

N.’nin psikoterapi sürecinde, ilk aşamada, kabul ve saygı gördügünü hissedebileceği, empati temelli bir yaklaşım hedeflenmiş; bu tarz bir ilişkinin N.'nin psikoterapi sürecine güven duyabilmesi ve iyileşmesi açısından önemli bir temel oluşturacağı düşünülmüştür. Strupp (1988), yaptığı araştırma sonucunda, psikoterapist ve hasta arasında, ilk üç seansta kurulan ilişkinin, tedavi sonuçlarını yordadığını belirtmiştir. Bu ilk görüşmelerde, psikoterapist, hastanın olumsuz duygulanım ve davranışlarına içten ve sıcak yaklaşabildiğinde, olumlu bir ilişkinin temelleri atılabilmektedir. Bunun aksine, psikoterapistin olumsuz, düşmancıl ve kontrolcü olarak algılanabilecek davranışları, psikoterapinin sonuçlarını olumsuz etkilemektedir. N. ile olumsuz duygularını rahatlıkla aktarabileceği, saygı ve değer gördüğü bir ilişki kurulmaya çalışılmıştır. Bu süreçte, N.'nin geçmiş ilişki deneyimlerine bağlı olarak, karşısındaki kişilerin suçlayıcı, yargılayıcı olabileceğine dair inanc1, ilk görüşmelerde, kendisinden bahsetmekte güçlük yaşamasına neden olmuş; psikoterapist, bu ketlenme ve kendisine yansıtılan rol karşısında yaşadığı engellenme ve çaresizlik hissini, süpervizyon desteği ile anlamlandırma ve psikoterapi sürecinde olumlu kazanımlara dönüştürme şansı bulmuştur.

Wright ve Davis (1994), vaka çalışması temelinde, hastalara psikoterapi ilişkisinden beklentilerini sorduklarında aldıkları yanıtlardan hipotetik bir mektup oluşturmuşlardır. Bu mektupta, ilişkideki güven, profesyonellik, saygı (örn., hastaya canım/hayatım gibi hitap tarzları kullanmama, aşırı soğuk durarak özneden ziyade nesne gibi hissettirmeme), hastayı sürece dair bilgilendirme, hasta hakkında tek bir formulasyona takılıp kalmadan esnek düşünebilme ve terapistin hastaya "aşırı yorgun, mutsuz, gergin" görünmemesi gibi boyutların önemi vurgulanmaktadır. N. ile psikoterapi sürecinde, bu öneriler psikoterapist açısından faydalı olmuştur. Psikoterapist, ilişki kurma sürecinde esnek, savunmacı olmayan bir tutum benimseyerek, N.'nin yaşantı ve hislerini paylaşabilmesini yüreklendirmiştir. N. ile ilişki kurmada, kabul edici, esnek yaklaşımın ve mizah kullanımının faydalı olduğu düşünülmektedir.

Sonuç olarak, N. ile psikoterapi süreci, Boelen ve arkadaşlarının (2006) önerdiği bilişsel model temelinde gerçekleştirilmiştir. Terapi ilişsisinin ve bilişsel modelin, N.'nin yas sürecini hafızasında entegre edebilmesinde, bu kaybın ve yaşam öyküsünün, yas sürecini nasıl etkilediğini fark edebilmesinde etkili olduğu düşünülmektedir. N., bu farkındalık ve entegrasyonun desteği ile geleceğe yönelik umutlu planlar yapabilmekte, daha fazla olumlu duygu deneyimleyebilmekte ve sosyal ilişkilerinde kendisini daha rahat ifade edebilmektedir. Psikoterapi sürecinde, N.'nin anne kaybına bağlı komplike yası üzerine çalışıldığında, depresif belirtilerinde azalma olduğu düşünülmektedir. 


\section{Kaynaklar}

American Psychiatric Association (2013). Diagnostic and Statistical Manual of Mental Disorders (5th ed.).Washington, DC: American Psychiatric Association.

Adler, N., Boyce, T., Chesney, M. A., Cohen, S., Folkman, S., Kahn, R. L., Syme, S. L. (1994). Socioeconomic status and health: the challenge of the gradient. AmericanJournal of Psychology, 49, 15-24.

Beder, J. (2004). Voices of Bereavement: A Casebook for Grief Counselors. Brunner \& Routledge: Great Britain.

Boelen, P. A. \& Van den Bout, J. (2005). Complicated grief, depression, and anxiety as distinct postloss syndromes: A confirmatory factor analysis study. American Journal of Psychiatry, 162, 2175-2177.

Boelen, P. A., Van den Hout, M. \& Bout, J. (2006). A cognitive- behavioral conceptualization of complicated grief. Clinical Psychology: Science and Practice, 13 (2), 09-128.

Boelen, P. A. \& Van den Bout, J. (2010). Anxious and depressive avoidance and symptoms of prolonged grief, depression, and post-traumatic stress disorder. Psychologica Belgica, 50, 1,49-67. Boelen, P. A. \& Klugkist, I. (2011). Cognitive behavioral variables mediate the associatives of neuroticism and attachment insecurity with prolonged grief disorder severity. Anxiety, Stress and Coping, 24 (3), 291-307.

Boelen, P. A., Keijser, J., Lehman, D. R., Tweed, R. G., Haring, M., Sonnega, J., Carr, D., Nesse, R. M. (2011). Factors associated with outcome of cognitive-behavioural therapy for complicated grief: A preliminary study. Clinical Psychology and Psychotherapy, 18, 284- 291.

Bonanno, G. A., Wortman, C. B. , Lehman, D. R., Tweed, R. G., Haring, M., Sonnega, J., Carr, D., Nesse, R. M. (2002). Resilience to loss and chronic grief: A prospectivestudy from preloss to 18 months post-loss. Journal of Personality and Social Psychology, 83, 11501164. Bowlby, J. (1982). Attachment and loss: Vol. 3. Loss, sadness, and depression. NewYork: Basic Books.

Burton, C. L., Yan, O., Pat-Horenczky, R., Chan, I. S., Ho, S., Bonanno, G. A. (2012). Coping flexibility and complicated grief: A comparison of American and Chinese samples. Depression \& Anxiety, 29 (1), 16-22.

Casarett, D., Kutner, J. S., Abrahm, J. (2001). Life after death: A practical approach to grief and bereavement. Annals of Internal Medicine, 134, 208-215.

Chiu, Y., Yin, S., Hsieh, H. Y., Wu, W. C., Chuang, H. Y., Huang, C. T. (2010). Bereaved females are more likely to suffer from mood problems even if they do not meet the criteria for prolonged grief . Psycho-Oncology, 20, 1061-1068.

Craig, L. (2010). Prolonged grief disorder. Oncology Nursing Forum, 37 (4), 401-405.

Cowhock, F., Ellestad, B., Meador, K. G., Koenig, H. G., Hoosen, E. G., Swamy, G. K. (2011).

Religiosity is an important part of coping with grief in pregnancy after a traumatic secondtrimester loss. Journal of Religion \& Health, 50 (4), 901-910.

Currier, J. M., Holland, J. M. \& Neimeyer, R.A. (2009). Assumptive worldviews and problematic reactions to bereavement. Journal of Loss and Trauma, 14, 181-195.

Dell'Osso, L., Carmassi, C., Corsi, M., Pergentini, I., Socci, C., Maremmani, A., Perugi, G. (2011). Adult separation anxiety in patients with complicated grief versus healthy control subjects: relationships with lifetime depressive and hypomanic symptoms. Annals of General Psychiatry, 10:29, 1-6.

Freud, S. (2000). Yas ve Melankoli. Metapsikoloji (s.179-191) Çev. Yardımlı, A. Birinci Basım. 
İdea Yayınevi: İstanbul. (Özgün eser 1915 tarihlidir).

Gamino, L. A., Sewell, K. W., \& Easterling, L. (2000). Scott and White grief study Phase 2:

Toward an adaptive model of grief. Death Studies, 24, 633-660.

Ghesquiere, A., Haidar, Y. M. M., Shear, M. K. (2011). Risks for complicated grief in family caregivers. Journal of Social Work in End-of-Life \& Palliative Care, 7, 216-240.

Gona, K. \& K'Delant, P. (2011). The effects of temperament, character, and defense mechanisms of grief severity among the elderly. Journal of Affective Disorders, 128, 1-2, 128-134.

Harvard Mental Health Letter (HMHL) (2011). Coping with complicated grief. Harvard Mental Health Publications, 6.

Hollis, James (2004). Ruhun Kaygan Kumları. Çev. Toksoy, S., Erendağ, Ç. Birinci Basım.

Sistem Yayıncilık: İstanbul.

Horowitz, M. J., Siegel, B., Holen A., Bonanno, G. A., Milbrath, C., Stinson, C. H. (1997).

Diagnostic criteria for complicated grief disorder. American Journal of Psychiatry, 154, 904-910.

Kelley, M. M., Chan, K. T. (2012). Assessing the role of attachment to God, meaning, andreligious coping as mediators in the grief experience. Death Studies, 36, 199-227.

Kessler, R. C., Kendler, K. S., Heath, A., Neale, M. C., Eaves, L. J. (1992). Social support, depressed mood, and adjustment to stress: a genetic epidemiologic investigation. Journal of Personality and Social Psychology, 62- 257-272.

Kübler-Ross (1969). On Death and Dying. MacMillan: New York.

Kristensen, P., Weisaeth, L. \& Heir, T. (2012). Bereavement and mental health after sudden and violent losses: A Review. Psychiatry, 75 (1), 76-97.

Le Guin, U. (1999). Yerdeniz Büyücüsü. İstanbul: Metis Edebiyat.

Lindemann (1963). Symptomatology and management of acute grief. Pastoral Psychology, 14 (6), 8-18.

Lobb, E. A., Kristjanson, L., Samar, M., Leanne, M., Georgia, K. B., Halkett, A. D. (2010). Predictors of complicated grief: A systematic review of empirical studies. Death Studies, 34, 673-698.

Love, A. W. (2007). Progress in understanding grief, complicated grief, and caring for the bereaved. Contemporary Nurse, 27 (1), 73-83.

Maccallum, F. \& Bryant, R. A. (2011). Imagining the future in complicated grief. Depression and Anxiety, 28, 658-665.

Maercker, A., Bonnanno, G. A., Znoj, H. \& Horowitz, M. J. (1998). Prediction of complicated grief by positive and negative themes in narratives. Journal of Clinical Psychology, 54 (8), 1117-1136.

Maercker, A. \& Lalor, J. (2012). Diagnostic and clinical considerations in prolonged griefdisorder. Dialogues in Clinical Neuroscience, 14 (2), 167-175.

Mathew, L. T. \& Marwit, S. J. (2004). Complicated grief and the trend toward cognitive behavioral therapy. Death Studies, 28, 849-863.

Melhem, N. M., Day, N., Shear, K., Day, R., Reynolds III, C., Brent, D. (2003). Predictors of complicated grief among adolescents exposed to a peer's suicide. Journal of Loss and Trauma, 9, 21-34.

Metzger, P. \& Gray, M. (2008). End-of-Life communication and adjustment: Pre-loss communication as a predictor of bereavement-related outcomes. Death Studies, 32, 301- 325.

Nakao, M., Kashiwagi, M., Yano, E. (2005). Alexithymia and grief reactions in bereaved Japanese women. Death Studies, 29, 423-433.

Neimeyer, R. A. (2006). Complicated grief and reconstruction of meaning: Conceptual and 
empirical contributions to a cognitive-constructivist model. Clinical Psychology: Science and Practice, 13, 141-145.

Newson, R. S., Boelen, P.A. \& Hek, K. (2011). The prevalance and characteristics of complicated grief in older adults. Journal of Affective Disorders, 132, 1-2, 231-238.

Ogrodniczuk, J. S., Piper, W. E., Joyce, A. S., Weideman, R., McCallum, M., Azim, H. F., Rosie, J. S. (2003). Differentiating symptoms of complicated grief and depression amongpsychiatric outpatients. The Canadian Journal of Psychiatry, 48 (2), 87-93.

Parkes C. M. (1998). Traditional models and theories of grief. Bereavemnt Care, 17 (2), 21-23. Parkes, C. M. (2002). Grief: lessons from the past, visions for the future. Death Studies, 26, 367385.

Prigerson, H. G., Horowitz, M.J., Jacobs, S. C., Parkes, C. M., Aslan, M., Goodkin, $\quad$ K...Maciejewski, P. K. (2009). Prolonged grief disorders: Psychometric validation of criteria proposed for DSM-V and ICD-11. Plos Med, 6 (8).

Raphael, B. \& Dobson, M. Bereavement. In Loss and trauma: General and close relationship perspectives, ed. By. Harvey, J. H. \& Miller, E. D. (2000). Brunner \& Routledge: UK Sussex. Robinson \& Marwit, S.J. (2006). An investigation of the relationship of personality, coping, and grief intensity among bereaved mothers. Death Studies, 30, 677-696.

Schnider, K. R \& Elhai, J. D. (2007). Coping style use predicts posttraumatic stress and complicated grief symptom severity among college students reporting a traumatic loss. Journal of Counseling Psychology, 54 (3), 344-350.

Shear, K. \& Shair, H. (2005). Research reiew: Attachment, loss, and complicated grief. Developmental Psychobiology, 47, 253-267.

Shear, M. K.., Simon, N., Wall, M., Zisook, S., Neimeyer, R., Duan, N...Kesaviah, A. (2011). Complicated grief and related bereavement issues for DSM-5. Depression and Anxiety, 28, 103-117.

Shear, M. K. (2012). Getting straight about grief. Depression and Anxiety, 29: 461-464.

Stroebe M, Schut H, Stroebe W (2007). Health outcomes of bereavement. Lancet 370: 19601973.

Stroebe, M., Boelen, P. A., Van den Hout, M., Stroebe W., Salemlnk, E., Van den Bout J. (2007). Ruminative coping as avoidance: A reinterpretation of its function in adjustment o bereavement. Eur Arch Psychiatry Clin Neurosci, 257, 462-472.

Strupp, H. (1988). What is therapeutic change? Journal of Cognitive Psychotherapy, 2 (2), 75 82.

Sung, S. C., Dryman,, M. T., Marks, E., Shear, M. K., Ghesquiere, A., Fava, M., Simon, N. M. (2011). Complicated grief among individuals with major depression: Prevalence, comorbidity, and associated features. Journal of Affective Disorders, 134, 1-3, 453-458.

Tomarken, A., Holland, J., Schacher, S., Vanderwerker, L., Zuckerman, E., Nelson, C...Prigerson, H. (2008). Factors of complicated grief pre-death in caregivers of cancer patients. Psycho-Oncology, 17, 105-111.

Tomarken, A., Roth, A., Holland, J., Ganz, O., Schachter, S., Kose, G....Nelson, C.J. (2012).

Examining the role of trauma, personality, and meaning in young prolonged grievers.

Psycho-Oncology, 21, 771-777.

Worden, J. W. (1996). Children and Grief: When A Parent Dies. New York: Guilford Press. Worden, J. W. (2004). Grief Counseling and Grief Therapy: A Handbook for the Mental Healh Practitioner. Brunner \& Rutledge: New York. Third Edition.

Worden, J. W. (2009). Grief Counseling and Grief Therapy: A Handbook for the Mental Healh 
Practitioner. Brunner \& Rutledge: New York. Fourth Edition.

Wright, J. H. \& Davis, D. (1994). The therapeutic relationship in cognitive-behavioral therapy: Patient perceptions and therapist responses. Cognitive and Behavioral Practice, 1, 25-45.

Zisook, S., Corruble, E., Duan, N., Igiewicz, A., Karam, M. D., Lanuoette, N....Young, I. T. (2012). The bereavement exclusion and DSM-5. Depression and Anxiety, 29, 425-443. 


\section{Ek 1. DSM-V Süreğen Kompleks Yas Bozukluğu}

\section{DSM-V Süreğen Kompleks Yas Bozukluğu Tanı Kriterleri}

A. Kişi yakın ilişkisi olan birini kaybetmiştir.

B. Ölümünden bu yana aşağıdaki semptomlardan en az birinin olduğu günler, olmayanlardan fazladır. Bu belirtiler, yetişkinlerde, kayıptan sonraki 1 yıl; çocuklar için ise 6 ay boyunca belirgindir.

1. Süreğen hasret duygusu. Küçük çocuklarda, hasret oyunlarda ve davranışlarda görülebilir. Çocuk ayrılma ve tekrar birleşme ile ilişkili davranışlar sergileyebilir.

2. Kayıp karşısında duyulan yoğun üzüntü ve ızdırap

3. Zihnin kaybedilen kişi ile meşgul olması

4. Ölüm biçimi ve koşulları ile ilgili zihinsel meşguliyet. Bu zihinsel meşguliyet, çocukların oyun ve davranışlarında ortaya çıkabilir.

C. Ölümden bu yana, aşağıdaki belirtilerden altı tanesi ya da daha fazlası mevcuttur. Ölümden bu yana aşağıdaki belirtilerden en az birinin olduğu günler, olmayanlardan fazladır. Bu belirtiler, yetişkinlerde, kayıptan sonraki 1 yıl; çocuklar için ise 6 ay boyunca belirgindir.

\section{Ölüme tepki olarak oluşan ıdırap}

1. Yakınının ölümünü kabullenmekte güçlük. Bu durum, çocuklarda, ölümün anlamını ve geri dönüşsüz olmasını kavrama kapasitesine bağlıdır.

2. Kaybın gerçekliğine inanamama veya duygusal uyuşmuşluk hissi

3. Kaybedilen kişi ile ilişkili olumlu anıları düşünmekte güçlük

4. Kayıpla ilişkili öfke ya da hoşnutsuzluk

5. Kişinin kaybedilen yakın ile ilişkisinde veya ölümdeki kendi yerine ilişkin olumsuz değerlendirmeler (örn., kendini suçlama)

6. Kaybı hatırlatan nesnelerden yoğun kaçınma (örn., kişilerden, yerlerden veya kaybedilen kişi ile ilişkilendirilen durumlardan kaçınma; çocuklarda, kaybedilen kişi ile ilgili düşünce ve hislerden kaçınmayı da kapsar)

\section{Sosyal Alanda Bozulma/ Kimlik Karmaşası}

7. Ölen kişi ile kavuşma isteğine bağlı intihar düşünceleri

8. Ölümden bu yana, insanlara güvenmekte güçlük

9. Yalnızlık ve izolasyon hissi

10. Kaybedilen kişi olmadan yaşamın anlamsız ve amaçsız gelmesi ya da onsuz yaşayamayacağı inanc1

11. Yaşamdaki rolüne ilişkin karmaşa veya kimlik kaybı (örn., kişinin yakınının ölümü ile kendisinin bir parçası ölmüş gibi hissetmesi)

12. İlgi alanlarını, ilişkileri devam ettirmekte ve gelecek planları konusunda zorluk ya da isteksizlik (örn., arkadaşlıklar, aktiviteler)

D. Bu belirtiler kişinin yaşamında yoğun 1zdırap veya iş, sosyal yaşam gibi önemli alanlarda işlevsellik kaybına yol açmaktadır 
E. Yas tepkileri, kültürel normlara, dini ve ya yaş normlarına göre olağandan fazladır.

\section{Travmatik kayıp var ise belirtiniz.}

Travmatik Kayıp: Cinayet ya da intihara bağlı kayıp ve ölüm biçimine ilişkin ızdırap verici zihinsel meşguliyet (özellikle kaybı hatırlatan durum ya da nesneler ile karşılaşıldığında). Bu zihinsel meşguliyet, kaybedilen kişinin son dakikaları, yaraları, çektiği ızdırap ya da ölümün kötücül ve kasitlı olmasına dair olabilir. 


\section{Summary \\ Complicated Grief: Literature Review and a Case Study}

The current article covered a brief literature review on grief, the factors affecting the grief process leading to complicated grief reactions and depressive symptoms and focused on the psychotherapy process of an individual with complicated grief reactions. Complicated grief reactions is a current topic in research and psychotherapy that led American Psychiatric Association (APA) to include a diagnostic criteria named "Persistent Complex Bereavement Disorder" (PCBD) under the heading of "Conditions for Further Study". As the term "complicated grief" (CG) rather than PCBD was widely used in the current literature, this term was used in this article. CG encompasses symptoms such as separation distress (e.g., craving, yearning, intense feelings of loneliness, desiring to die in order to reunion, preoccupation with thoughts of the deceased) and other cognitive, emotional, and behavioral symptoms (e.g., confusion, disbelief, avoidance, anger, numbness, difficulty moving on with life). In the literature, many precipating factors for complicated grief reactions were reported. These factors involve the type of death, personal well-being, the relationship with the deceased, personality characteristics, coping style, schemas and beliefs, and social support. These factors that result in complicated grief reactions may be helpful in understanding complicated grief and its treatment. In this article, after the literature review on complicated grief, a treatment model and its application in the psychotherapy process of $\mathrm{N}$. was mentioned. According to this cognitive model that was suggested by Boelen and his collegues (2006), core processes such as poor integration of the separation with existing autobiographical knowledge, negative global beliefs and misinterpretations and anxious and depressive avoidance strategies moderate the relationship between some background variables (e.g., individual vulnerabilty factors, characteristics of the loss event, characteristics of the loss sequelae) and the clinical outcomes (e.g., separation distress, traumatic distress). Boelen and his collegues (2006) state that the treatment of complicated grief should have three targets: 1) loss needs to be conceptually processed and integrated within the autobiographical memory 2) dysfunctional beliefs and misinterpretations need to be identified and replaced with functional ones 3) anxious and depressive avoidance strategies need to be replaced with helpful strategies promoting adjustment. The model does not restrict cognitive behavioral techniques. In order to reach these goals, Boelen and his collegues (2006) suggest using techniques such as psychoeducation, exposure, Socratic questioning and cognitive restructuring. Therefore the psychotherapy process involved a collaborative therapeutic relationship and cognitive behavioral techniques while focusing on the integration of loss in memory, dysfunctional beliefs and avoidance strategies in order to replace them with more adaptive ones. 